\title{
Characterization of the hydraulic performance of self-compensating emitters with water of different salt concentrations ${ }^{1}$
}

\author{
Caracterização da performance hidráulica de emissor \\ autocompensante com água de diferentes concentrações salinas
}

\author{
Patrícia Ferreira da Silva ${ }^{2 *}$; Rigoberto Moreira de Matos $^{3}$; José Dantas Neto \\ Roberta de Cássia Barros Gomes ${ }^{5}$; Vera Lúcia Antunes de Lima ${ }^{4}$
}

\begin{abstract}
The aim of the present study was to evaluate hydraulic characteristics such as manufacturing and flow variation coefficient, characteristic equation of self-compensating emitters and the variation between nominal flow and that obtained by the emitter equation using waters of different salt concentrations. The research was conducted in the greenhouse of the Academic Unit of the Agricultural Engineering, Federal University of Campina Grande-PB. Treatments consisted of five salinity levels in the irrigation water (ECwi) $\left(0.6 ; 1.5 ; 2.5 ; 3.5\right.$ and $4.5 \mathrm{dS} \mathrm{m}^{-1}$ at $\left.25^{\circ} \mathrm{C}\right)$ and four working pressures $(60,100,140$, and $160 \mathrm{kPa}$ ), with three replicates. The flow variations of emitters were considered small over time, being within recommendation of $\pm 7 \%$ of the nominal flow with " $\mathrm{x}$ " exponent values between 0.02 and 0.09 , as recommended by the manufacturer, which was classified as self-compensating. The manufacturing and flow variation coefficients were considered excellent in all evaluations and the operating time did not influence the hydraulic performance of emitters. At pressure of $60 \mathrm{kPa}$ and electric conductivity of $0.6 \mathrm{dS} \mathrm{m}^{-1}$, flow rates near values provided by the manufacturer and more economically viable to the farmer were obtained.
\end{abstract}

Key words: Nominal flow. Manufacturing variation coefficient. Salinity. Characteristic equation.

\section{Resumo}

Objetivou-se, com o presente estudo, avaliar as características hidráulicas, como coeficiente de variação de fabricação e vazão, equação característica do emissor autocompensante e a variação entre a vazão nominal e a obtida pela equação do emissor utilizando águas de diferentes concentrações salinas. A pesquisa foi conduzida na casa de vegetação da Unidade Acadêmica de Engenharia Agrícola, Universidade Federal de Campina Grande-PB. Os tratamentos foram compostos por cinco níveis de salinidade da água de irrigação (CEai) $\left(0,6 ; 1,5 ; 2,5 ; 3,5\right.$ e $4,5 \mathrm{dS} \mathrm{m}^{-1}$ a $\left.25^{\circ} \mathrm{C}\right)$ e quatro pressões de serviço $(60,100,140$, e $160 \mathrm{kPa})$, com três repetições. As variações de vazão dos emissores foram consideradas pequenas ao longo do tempo, de modo que estavam dentro da recomendação de $\pm 7 \%$ da vazão nominal, com valores de expoente "x" entre 0,02 e 0,09, segundo recomendação do fabricante, que os classificou como autocompensantes. Os Coeficientes de variação de fabricação e de vazão foram considerados excelentes em todas as avaliações e o tempo de funcionamento não influenciou no desempenho hidráulico dos emissores. Na pressão de $60 \mathrm{kPa}$ associada à condutividade elétrica da água de $0,6 \mathrm{dS} \mathrm{m}^{-1}$, obtiveram-se vazões dos emissores mais próximas da declarada pelo fabricante e a mais economicamente viáveis ao produtor.

Palavras-chave: Vazão nominal. Coeficiente de variação de fabricação. Salinidade. Equação característica.

${ }^{1}$ Parte da Dissertação de Mestrado do Primeiro Autor.

2 Discente do Curso de Doutorado em Enga Agrícola, Universidade Federal de Campina Grande, UFCG, Campina Grande, PB, Brasil. E-mail: patrycyafs@yahoo.com.br

${ }^{3}$ Discente do Curso de Mestrado em Enga Agrícola, UFCG, Campina Grande, PB, Brasil. E-mail: rigobertomoreira@gmail.com

${ }^{4}$ Profs. Titulares, Unidade Acadêmica de Eng ${ }^{a}$ Agrícola, UFCG, Campina Grande, PB, Brasil. E-mail: zedantas1955@gmail.com; antuneslima@gmail.com

5 Discente do Curso de Graduação em Enga Agrícola, UFCG, Campina Grande, PB, Brasil. E-mail: robeert4@hotmail.com

* Author for correspondence 


\section{Introduction}

The increase in water consumption due to population growth and production activities, linked to environmental degradation of water bodies, has generated a situation of water scarcity in many regions of the world, which has changed habits especially in irrigated agriculture, which has sought to reduce consumption of water resources by optimizing irrigation systems (SILVA et al., 2012).

According to Najafi et al. (2010), due to the scenario of water scarcity and with regard to irrigation systems, there is preference for drip irrigation, whose expansion has remarkable record due to water and energy savings, and enabling automation and fertigation; however, care must be taken when using drip irrigation, which is subject to flow changes, whose consequences may result in flow obstruction, given that drip irrigation occurs through the use of emitters with holes of reduced diameter for water passage (CUNHA et al., 2013).

Emitters are the most sensitive part of this irrigation system and should ensure the supply of water to soil and plant, with acceptable uniformity throughout the unit to be irrigated. From the hydraulic standpoint, emitters are characterized by the required operating pressure and its nominal flow, and information regarding the flow of emitters and their flow regime is essential for the design and management of a drip irrigation system. For both, this information is obtained through characteristic equations of emitters, which are expressed by pressure-flow relationships (YILDIRIM, 2007).

In drip irrigation systems, mathematical modeling helps the construction of flow vs. available pressure curve at the input of emitters and is done with the aid of a potential-type equation (ALVES et al., 2008). However, in the particular case of the so-called self-compensating emitters, it is desirable that the load pressure exponent is the closest to zero as possible in order to minimize flow variations due to variations in working pressures. The maintenance of materials and equipment of drip irrigation systems has compromised the efficiency in the application of lower quality water, thus the knowledge of system performance is crucial when used in the application of saline water.

Given the relevance of the theme, this study aimed to evaluate hydraulic characteristics such as manufacturing variation and flow coefficient, characteristic equation of the self-compensating emitter and the variation between nominal flow and that obtained by the emitter equation using water with different salt concentrations.

\section{Material and Methods}

\section{Description of the experimental structure and system operation}

The experiment was conducted in a greenhouse belonging to the Federal University of Campina Grande-PB. The experimental area is located in geodetic coordinates: 712 ' 88 ' $\mathrm{S}, 35^{\circ} 54$ ' 40” W and average altitude of $532 \mathrm{~m}$; for the experiment, a masonry structure with three experimental modules and five water tanks for supply of emitters was used.

The pressurization system consisted of a $0.5 \mathrm{hp}$ centrifugal pump, with beginning of the working operation of $6 \mathrm{~h}$ and end of each application cycle of $11 \mathrm{~h}$ manually performed, according to beginning, application duration and flow schedules.

To prevent the entry of suspended particles into the system with size larger than the diameter of emitters, a 1" screen filter with flow capacity of $5 \mathrm{~m}^{3} \mathrm{~h}^{-1}$ and a Bourdon gauge were used to measure the operating pressure applied to the system. The emitters used in the experiment are self-compensating, so that technical characteristics regarding flow, pressure, model, spacing and hole diameter are shown in Table 1. 
Table 1. Technical data of emitter model XFS dripline from Rain Bird.

\begin{tabular}{lcccccccc}
\hline Manufacturer & Model & Flow & $\varnothing \mathrm{N}$ & Pressure & $\begin{array}{c}\text { Spacing between } \\
\text { emitters }\end{array}$ & $\begin{array}{c}\text { Wall } \\
\text { thickness }\end{array}$ & $\varnothing \mathrm{I}$ & $\varnothing \mathrm{O}$ \\
\hline \multirow{2}{*}{ Rain Bird } & XFS & $\mathrm{L} \mathrm{h}^{-1}$ & $\mathrm{~mm}$ & $\mathrm{kPa}$ & $\mathrm{m}$ & $\mathrm{mm}$ & $\mathrm{mm}$ & $\mathrm{mm}$ \\
\cline { 2 - 9 } & 0612500 & 2.3 & 16.1 & $60-420$ & 0.3 & 1.2 & 13.6 & 0.76 \\
\hline
\end{tabular}

$\varnothing \mathrm{N}=$ nominal diameter; $\varnothing \mathrm{I}=$ internal diameter; $\varnothing=$ hole diameter.

Treatments were composed of the combination of two factors: five salinity levels in the irrigation water (ECwi) $\left(0.6,1.5,2.5,3.5\right.$ and $4.5 \mathrm{dS} \mathrm{m}^{-1}$ at $\left.25^{\circ} \mathrm{C}\right)$ and four working pressures $(60,100,140$, and $160 \mathrm{kPa}$ ), with three replicates. Waters of different salt concentrations were prepared by methodology proposed by Richards (1954).

\section{Data collection process}

The new emitters with 210 and 350 hours of operation were assessed, each row of emitters was individually assessed for different salinity levels and pressures studied. The flows of emitters were sampled according to methodology proposed by Keller and Karmeli (1974) and Deniculi et al. (1980), the flow rates of eight emitters were collected: the first emitter and emitters located at position 1/7, 2/7, $3 / 7,4 / 7,5 / 7,6 / 7$ and the last emitter, with the use of plastic collectors and the volume was measured in a $1000 \mathrm{ml}$ graduated cylinder. Time intervals were 5 minutes measured using a digital chronometer.

The flow rates of 24 emitters at each pressure were obtained, totaling 72 in the three evaluations and to the four pressures studied, a total of 288 collections for each salinity level were obtained, the time spent in each collection was 30 minutes with total of 6 hours for each collection in all treatments.

\section{Manufacturing and flow variance coefficient}

To evaluate the flow variations that occur among emitters due to differences inherent to the manufacturing process, the selected emitters were submitted to different working pressures. According to Solomon (1979), the manufacturing variation coefficient is virtually independent from the pressure used in the experiment, provided that it is within the operating range. From the flow data, average flow rate and standard deviation were calculated, Eq. 1; then, the manufacturing variation coefficient (MVC) and flow variation coefficient (FVC) were determined according to Eq. 2. This coefficient was used with the name of flow variation coefficient, since the manufacturing variation coefficient (MVC) could only be used in samples of new emitters.

$$
\delta=\sqrt{\frac{\sum_{i-1}^{\mathrm{n}}\left(\mathrm{Q}_{\mathrm{i}}-\overline{\mathrm{Q}}\right)^{2}}{\mathrm{n}-1}}
$$

where:

$\delta$ - Standard deviation;

Qi - Flow of each emitter;

$\bar{Q}$ - Average flow of emitters tested;

$\mathrm{n}$ - Number of samples.

$$
\mathrm{MVC}=\frac{\delta}{\bar{Q}} \text { and } \mathrm{FVC}=\frac{\delta}{\bar{Q}}
$$

where:

MVC - manufacturing variation coefficient;

FVC - flow variation coefficient;

$\delta$ - Standard deviation of sample;

$\overline{\mathrm{Q}}$ - Average flow of sample L.h $\mathrm{h}^{-1}$.

\section{Characteristic equation}

The flow vs. pressure curve and the flow adjusted for new issuers with 210 and 350 hours of operation were determined as Eq. 3. 


$$
q=k * p^{x}
$$

where:

$\mathrm{q}$ - Dripper flow L-h ${ }^{-1}$;

$\mathrm{k}$ - Specific coefficient of each emitter that also depends on $q$ and $p$ units;

$\mathrm{p}$ - Pressure available at the inlet of the dripper, $\mathrm{kPa}$;

$\mathrm{x}$ - Emitter exponent, which characterizes the dripper flow.

Data were evaluated by analysis of variance and ' $\mathrm{F}$ ' test at 0.05 probability level and in case of significance, linear and quadratic polynomial regression analysis was performed using SISVAR-ESAL statistical software (Lavras, MG) (FERREIRA, 2008).

\section{Results and Discussion}

The summary of the analysis of variance for the manufacturing variation coefficient (MVC) in new emitters and the flow variation coefficient (FVC) for emitters with 210 and 350 hours of operation as a function of salt water application and different working pressures is described in Table 2. It was observed that the salinity of the water used did not influence MVC for new emitters; however, when the flow variation coefficient after 210 to 350 hours of operation was observed, the salinity of the water applied significantly influenced at level of $\mathrm{p}<0.01$ and $\mathrm{p}<0.05$.

The working pressure influence the manufacturing and flow variation coefficient of emitters at level of $p<0.01$ and $p<0.05$. There was a linear effect for MVC in new emitters and for FVC in emitters with 210 and 350 hours of operation. The interaction between salinity of irrigation water and working pressure ( $\mathrm{S} \times \mathrm{P}$ ) was significant at ( $\mathrm{p}$ $<0.01$ ) for flow variation coefficient in emitters with 210 hours of operation, Table 2.

The manufacturing variation coefficient of emitters, when they are new, decreased with increasing working pressure provided to the system (Figure 1A). This decrease is possibly due to the increased demanded pressure, which favors the increase in water velocity and therefore a reduction in MVC. According to Solomon (1979), the manufacturing variation coefficient can be influenced by any change in temperature, pressure and molding cooling time, because it affects the characteristics of emitters such as size, shape, weight, surface roughness and resistance.

Table 2. Summary of the analysis of variance for the manufacturing variation coefficient (MVC) of new emitters and flow variation coefficient (FVC) for emitters with 210 and 350 hours of operation at different salinity levels and pressures studied.

\begin{tabular}{lcccc}
\hline \multirow{2}{*}{ Source of variation } & \multirow{2}{*}{ D.F } & MVC & FVC & FVC \\
\cline { 3 - 4 } & & New & $210 \mathrm{~h}$ & $350 \mathrm{~h}$ \\
\hline Salinity (S) & 4 & $0.001^{\mathrm{ns}}$ & $10.47^{* *}$ & $3.07^{*}$ \\
Linear regression & 1 & $0.002^{\text {ns }}$ & $18.94^{* *}$ & $2.32^{\mathrm{ns}}$ \\
Quadratic regression & 1 & $0.002^{\mathrm{ns}}$ & $0.96^{\mathrm{ns}}$ & $0.11^{\mathrm{ns}}$ \\
Pressure (P) & 3 & $57.00^{* *}$ & $5.33^{* *}$ & $3.26^{*}$ \\
Linear regression & 1 & $146.95^{* *}$ & $5.60^{*}$ & $9.13^{* *}$ \\
Quadratic regression & 1 & $21.75^{* *}$ & $2.17^{\mathrm{ns}}$ & $0.02^{\mathrm{ns}}$ \\
Interaction (S x P) & 12 & $0.002^{\text {ns }}$ & $4.02^{* *}$ & $1.66^{\mathrm{ns}}$ \\
\hline C.V $(\%)$ & & 43.97 & 23.56 & 29.97 \\
\hline
\end{tabular}

ns $, * *, *$ respectively not significant, significant at $\mathrm{p}<0.01$ and $\mathrm{p}<0.05$ according to the $\mathrm{F}$ test. 
Figure 1. Manufacturing variation coefficient (A) as a function of the working pressure applied to new emitters and FVC (B) for emitters with 210 hours of operation at different salinity levels and pressures studied.

(A)

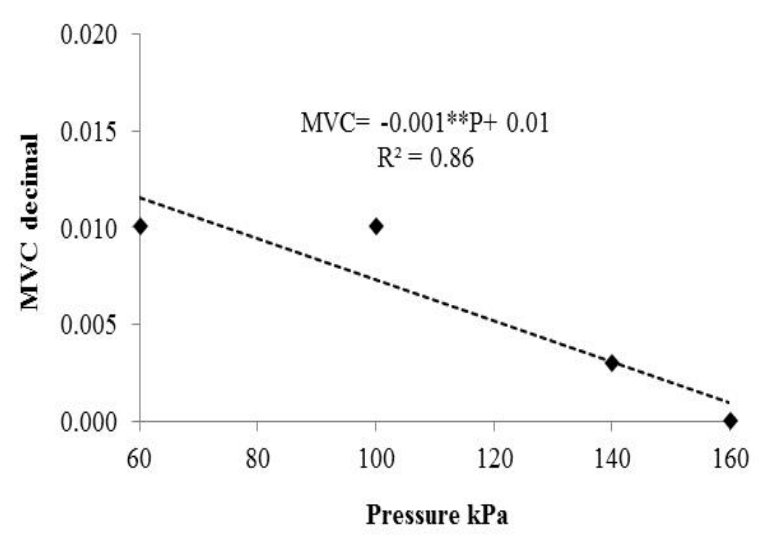

To this end, coefficients are classified as excellent, according to ASAE (1996), results that differ from those found by Silva et al. (2012) in a study on self-compensating emitters with different domestic sewage effluents, who concluded that the manufacturing variation coefficient was above $20 \%$ in all the pressure range studied.

The interaction for FVC in relation to emitters with 210 hours of operation is shown in Figure 1B. It has been found that the interaction among treatments was significant for pressures of 60,100 and $160 \mathrm{kPa}$. It was observed that, for pressure of $60 \mathrm{kPa}$, when the salinity level in the irrigation water increased, the flow variation coefficient also increased; however, for pressures of 100 and 160 $\mathrm{kPa}$, when water with electrical conductivity greater than $0.6 \mathrm{~d} \mathrm{Sm}^{-1}$ was applied, there was a decrease in FVC. This result was also observed by Lima et al. (2014), who studied the manufacturing and flow variation coefficients in self-compensating emitter using saline water. Whereas the flow cross sections are usually of small diameter, manufacture must
(B)

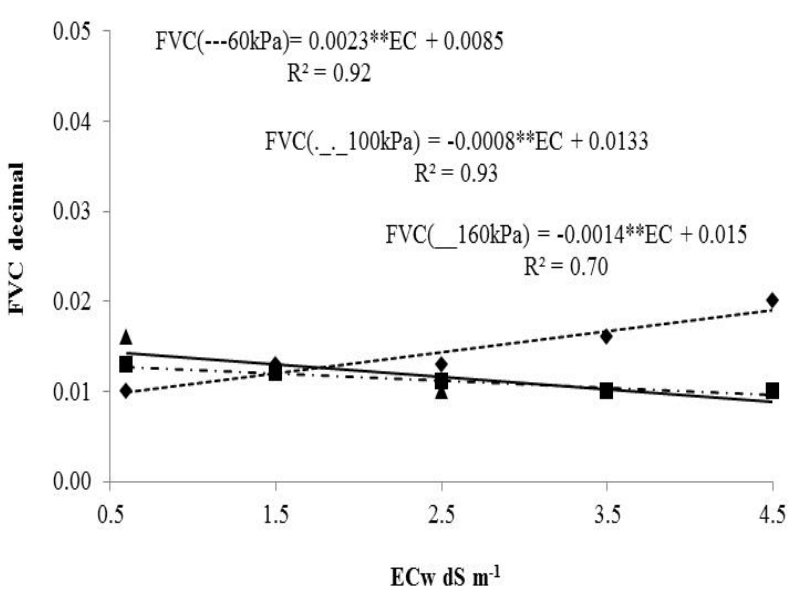

be accurate, uniform and constantly monitored because small variations in pressure can cause large differences in flow rate (FRIZZONE et al., 1998).

When flow variation coefficient with 350 hours of operation in the irrigation system was studied, the isolated effect of the working pressure was verified, whose reduction was $0.01 \%$ when the working pressure provided to the system increased (Figure 2A). The isolated effect for the salinity factor showed that as the water electrical conductivity increased, the manufacturing variation coefficient increased significantly (Figure 2B). Possibly, this is due to the accumulation of particles near the outlet orifices of emitters, which favors increasing flow variations.

The manufacturing and flow variation coefficients, even with all alterations due to the different treatments, are in accordance with ABNT recommendations (ABNT, 2006). Almeida et al. (2006) assessed the hydraulic behavior of drip irrigation emitters and found irregular manufacturing and flow variation coefficients. 
Figure 2. Flow variation coefficient as a function of the working pressure (A) and (B) the water salinity with 350 hours of operation.

(A)

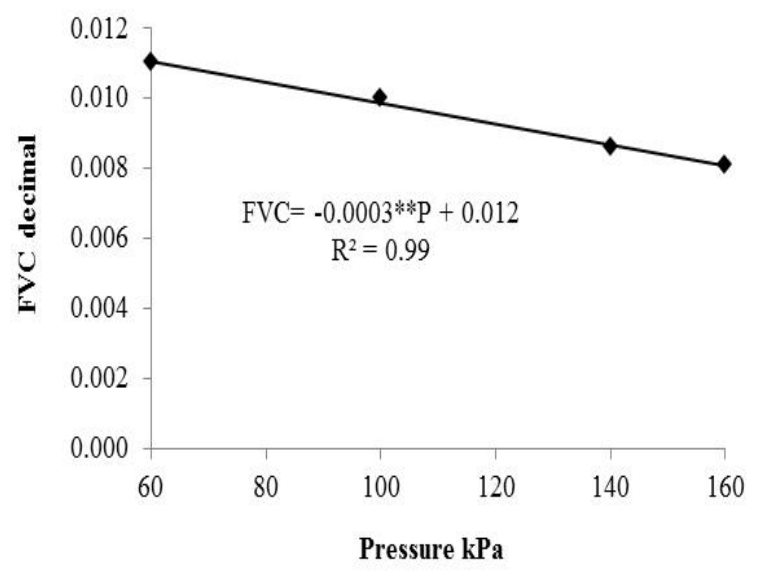

From the flow and its corresponding pressure, the equations that relate pressure and flow and the characteristic curve of new emitters for different salinity levels are determined (Figure 3). By regression analysis, the flow vs. pressure curve was obtained, observing that the characteristic curve for each treatment S1 $\left(0.6 \mathrm{dS} \mathrm{m}^{-1}\right), \mathrm{S} 2\left(1.5 \mathrm{dS} \mathrm{m}^{-1}\right), \mathrm{S} 3$ $\left(2.5 \mathrm{dS} \mathrm{m}^{-1}\right), \mathrm{S} 4\left(3.5 \mathrm{dS} \mathrm{m}^{-1}\right)$ and S5 $\left(4.5 \mathrm{dS} \mathrm{m}^{-1}\right)$ shows a potential equation with " $\mathrm{x}$ " values very close to zero $(0.073 ; 0.099 ; 0.087 ; 0.092$ and 0.093$)$, respectively.

It was also found that emitters are little susceptible to flow variation as a function of pressure, characterizing them as self-compensating, corroborating results found by Almeida et al. (2006) in which the potential equation presented value very close to zero (0.0974). According to ISO 9261 (ISO, 2004), when the " $x$ " exponent value of an emitter is less than 0.2 , it is considered self-compensating.

Garcia (2006), after evaluating the new selfcompensating dripper, obtained equations $\mathrm{q}=$ $1.288 \mathrm{H}^{0.075} ; \mathrm{q}=2.183 \mathrm{H}^{0.015}$ and $\mathrm{q}=1.926 \mathrm{H}^{0.034}$ with discharge " $x$ " exponent values of $0.075 ; 0.015$ and 0.034 , very close to those found in this experiment, although other models were used.
(B)

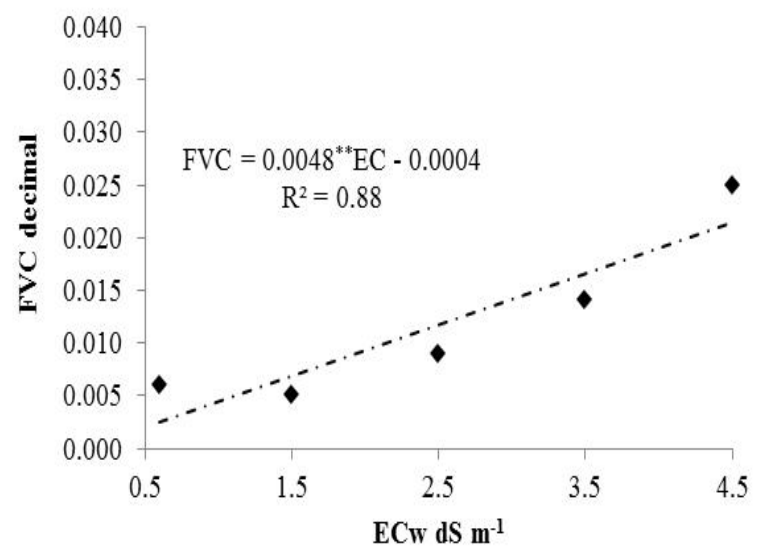

Pletsch et al. (2009) obtained in their study on the performance of drippers model Tiran 17, with flow rate of $2 \mathrm{~L} \mathrm{~h}^{-1}$ and spacing between drippers of $0.5 \mathrm{~m}$ using treated domestic sewage, curve characteristic of new emitter, which presents equation $\mathrm{q}=0,2417 \mathrm{H}$ ${ }^{0.47}$, with determination coefficient $\left(\mathrm{R}^{2}\right)$ of 0.995 and discharge exponent value " $\mathrm{x}$ " of 0.47 , disagreeing with values found in this study.

Silva et al. (2012) reported in their study on the performance of self-compensating emitters with different domestic sewage effluent comparing emitters used in field with some new emitters that new emitters were good at pressures of 100, 150 and $200 \mathrm{kPa}$, and regular for pressure of $250 \mathrm{kPa}$, indicating that for lower pressures recommended by the manufacturer, emitters obtained better performance.

The equation that relates flow and pressure of emitters and the characteristic curve with 210 hours of operation for different salinity levels is found in Figure 4. The potential equations for each salt treatment $\mathrm{S} 1\left(0.6 \mathrm{dS} \mathrm{m}^{-1}\right)$, S2 $\left(1.5 \mathrm{dS} \mathrm{m} \mathrm{m}^{-1}\right)$, $\mathrm{S} 3\left(2.5 \mathrm{dS} \mathrm{m}^{-1}\right), \mathrm{S} 4\left(3.5 \mathrm{dS} \mathrm{m}^{-1}\right)$ and S5 (4.5 dS $\left.\mathrm{m}^{-1}\right)$ demonstrated discharge " $\mathrm{x}$ " exponent values near zero $(0.090 ; 0.079 ; 0.089 ; 0.082$ and 0.083$)$, respectively, similar to values obtained when emitters were new. 
Figure 3. Flow vs. pressure curve with potential equation for new emitters at different salinity levels and pressures studied.

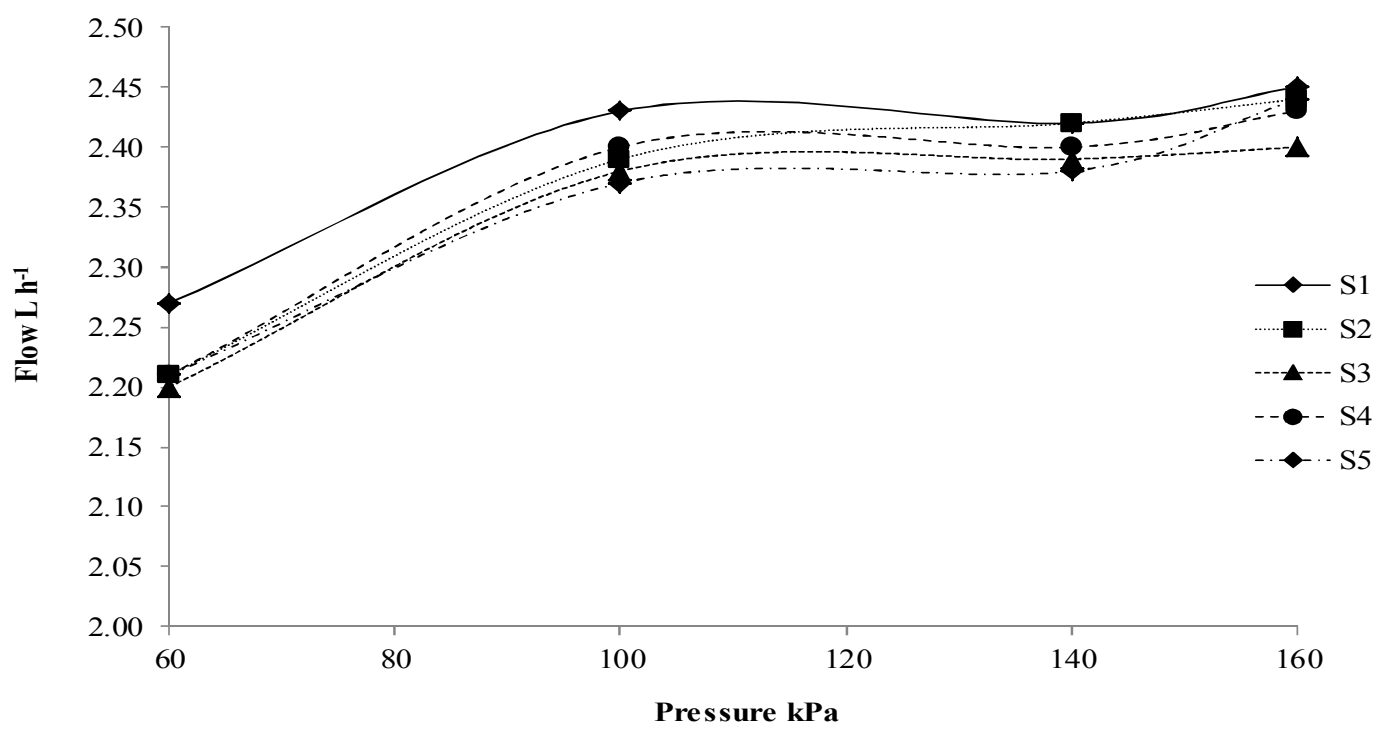

\begin{tabular}{ll}
\hline Treatments & Equation with $\mathrm{R}^{2}$ \\
\hline S1 $\left(0.6 \mathrm{dS} \mathrm{m}^{-1}\right)$ & $\mathrm{q}=1.69 \mathrm{P}^{0.073}$ \\
& $\mathrm{R}^{2}=0.83$ \\
$\mathrm{~S} 2\left(1.5 \mathrm{dS} \mathrm{m}^{-1}\right)$ & $\mathrm{q}=1.48 \mathrm{P}^{0.099}$ \\
& $\mathrm{R}^{2}=0.92$ \\
$\mathrm{~S} 3\left(2.5 \mathrm{dS} \mathrm{m}^{-1}\right)$ & $\mathrm{q}=1.55 \mathrm{P}^{0.087}$ \\
S4 $\left(3.5 \mathrm{dS} \mathrm{m}^{-1}\right)$ & $\mathrm{R}^{2}=0.85$ \\
& $\mathrm{q}=1.52 \mathrm{P}^{0.092}$ \\
S5 $\left(4.5 \mathrm{dS} \mathrm{m}^{-1}\right)$ & $\mathrm{R}^{2}=0.86$ \\
& $\mathrm{q}=1.51 \mathrm{P}^{0.0933}$ \\
& $\mathrm{R}^{2}=0.92$ \\
& \\
\hline
\end{tabular}

For Keller and Karmeli (1974), the " $x$ " exponent characterizes the flow regime and flow vs. pressure ratio of the emitter so that for $0<\mathrm{x}<0.5$, the flow regime varies from turbulent to fully turbulent and the flow suffers less influence from pressure variations. For $0.5<\mathrm{x}<1.0$, the flow regime varies from unstable to laminar, verifying that flow suffers greater influence from pressure variations. The closer the " $x$ " exponent to 0 (self-compensating), the lower the emitter sensitivity to pressure variations.
The flow vs. pressure ratio for emitters with 350 hours of operation for different salinity levels is shown in Figure 5, which was obtained by regression analysis, where the characteristic curve for each treatment $\mathrm{S} 1\left(0.6 \mathrm{dS} \mathrm{m}^{-1}\right), \mathrm{S} 2\left(1.5 \mathrm{dS} \mathrm{m}^{-1}\right)$, $\mathrm{S} 3\left(2.5 \mathrm{dS} \mathrm{m}^{-1}\right), \mathrm{S} 4\left(3.5 \mathrm{dS} \mathrm{m}^{-1}\right)$ and S5 $\left(4.5 \mathrm{dS} \mathrm{m}^{-1}\right)$ presents potential type equation with " $\mathrm{x}$ " values near zero $(0.038,0.036,0.034,0.034$ and 0.029$)$, respectively. 
Figure 4. Flow vs. pressure curve with potential equation for emitters with 210 hours of operation at different salinity levels and pressures studied.

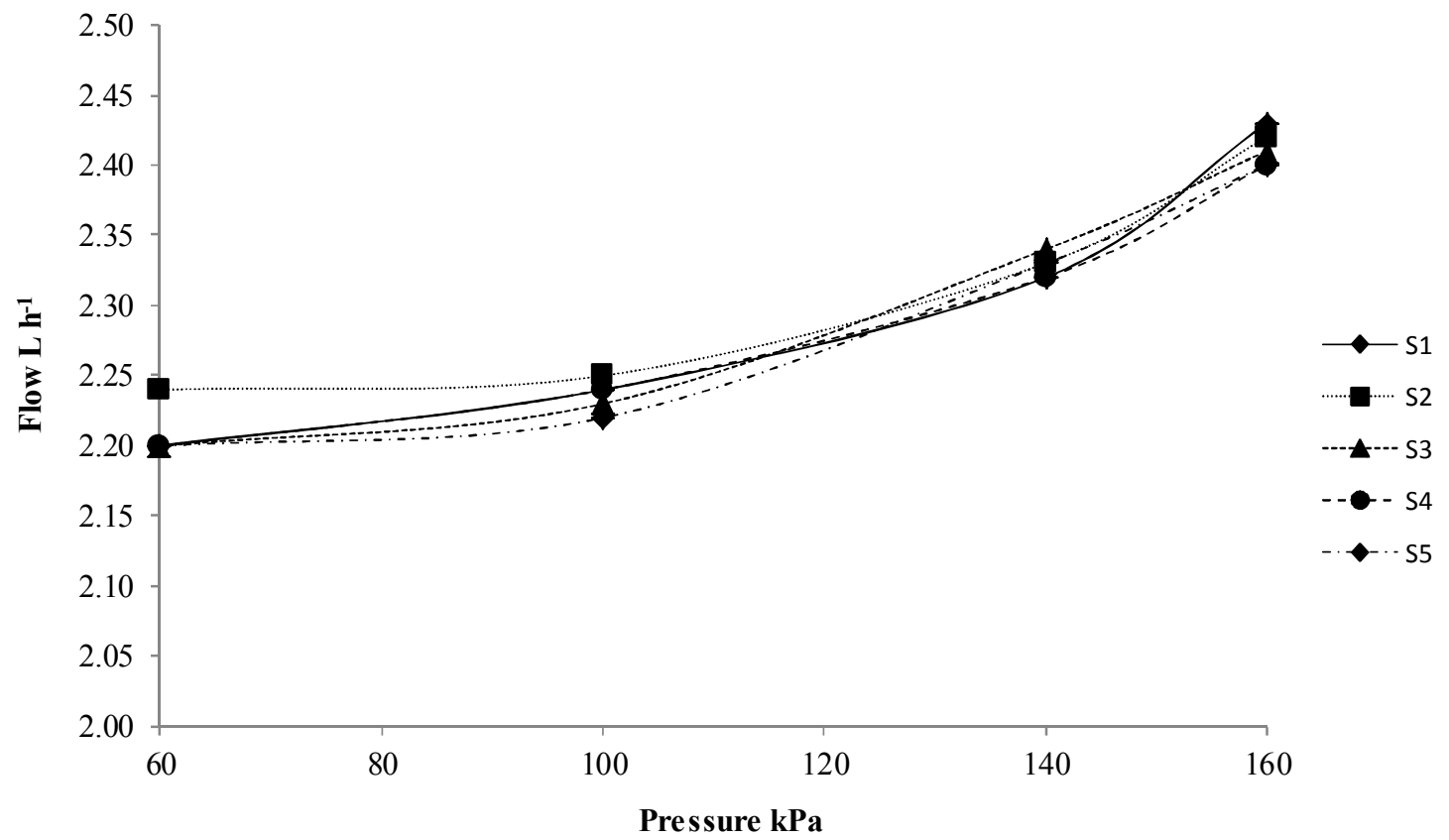

\begin{tabular}{ll}
\hline Treatments & Equation with $\mathrm{R}^{2}$ \\
\hline $\mathrm{S} 1\left(0.6 \mathrm{dS} \mathrm{m}^{-1}\right)$ & $\mathrm{q}=1.50 \mathrm{P}^{0.090}$ \\
& $\mathrm{R}^{2}=0.82$ \\
$\mathrm{~S} 2\left(1.5 \mathrm{dS} \mathrm{m}^{-1}\right)$ & $\mathrm{q}=1.65 \mathrm{P}^{0.0709}$ \\
& $\mathrm{R}^{2}=0.74$ \\
$\mathrm{~S} 3\left(2.5 \mathrm{dS} \mathrm{m}^{-1}\right)$ & $\mathrm{q}=1.50 \mathrm{P}^{0.089}$ \\
& $\mathrm{R}^{2}=0.85$ \\
$\mathrm{~S} 4\left(3.5 \mathrm{dS} \mathrm{m}^{-1}\right)$ & $\mathrm{q}=1.55 \mathrm{P}^{0.082}$ \\
& $\mathrm{R}^{2}=0.86$ \\
$\mathrm{~S} 5\left(4.5 \mathrm{dS} \mathrm{m}^{-1}\right)$ & $\mathrm{q}=1.53 \mathrm{P}^{0.083}$ \\
& $\mathrm{R}^{2}=0.82$ \\
\hline
\end{tabular}

According to Almeida et al. (2006), a selfcompensating emitter must present characteristic equation exponent ranging from 0 to 0.4 , which was demonstrated in this study, so they were classified as self-compensating, showing that the flow of emitters was little influenced by pressure variations.

Keller and Karmeli (1974) reported that the working pressure is of particular importance in pressurized irrigation because it affects the flow rate, the application efficiency and the water distribution uniformity. Working with pressure above values recommended by manufacturers, excessive fragmentation of water droplets can be caused due to the reduction of their size. Calculated " $x$ " exponent should not be very different from the value provided by the manufacturer by $\pm 5 \%$, according to ISO 9261 (ISO, 2004), however, it was not possible to make this comparison, since the manufacturer did not inform this coefficient in their catalogs. 
Figure 5. Flow vs. pressure curve with potential equation for emitters with 350 hours of operation at different salinity levels and pressures studied.

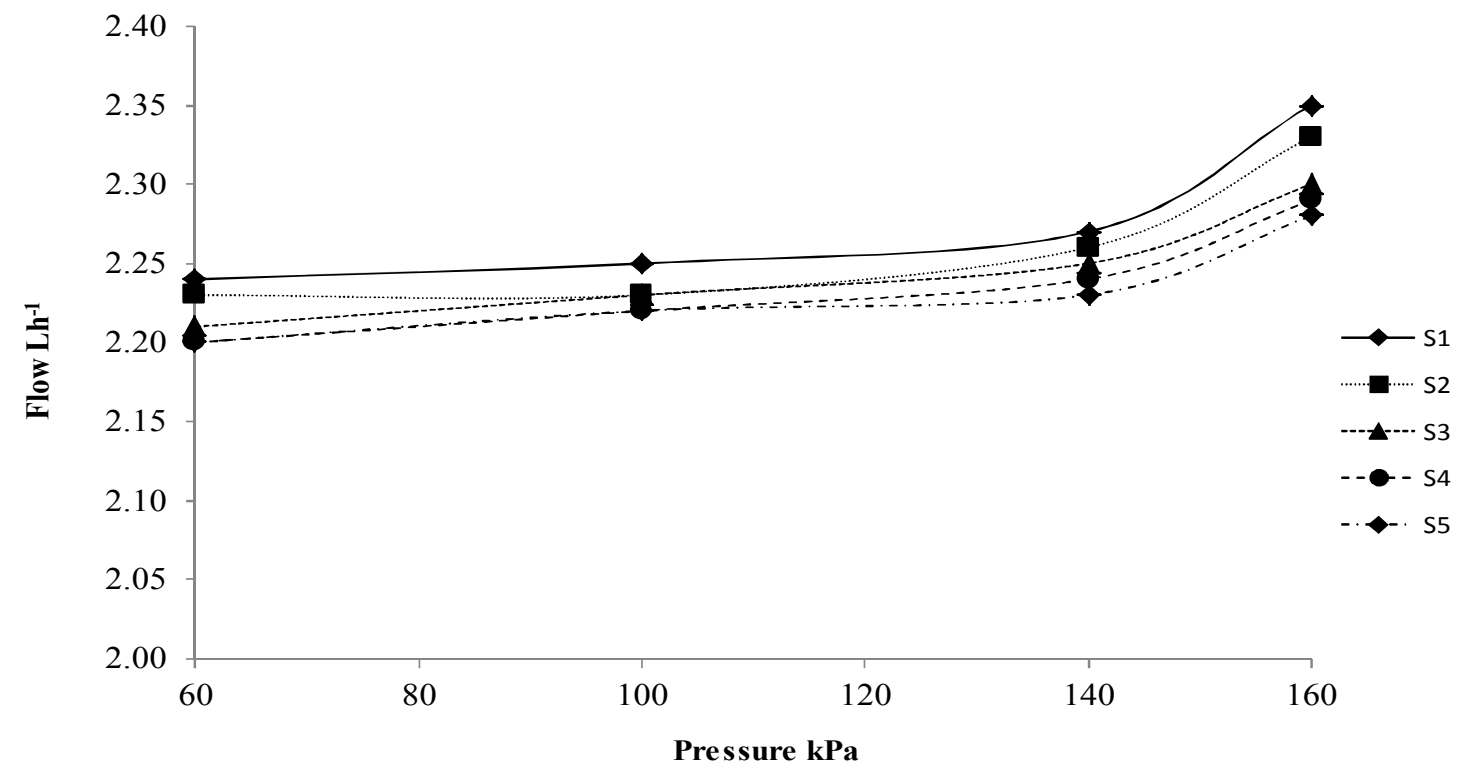

\begin{tabular}{ll}
\hline Treatments & Equation with $\mathrm{R}^{2}$ \\
\hline $\mathrm{S} 1\left(0.6 \mathrm{dS} \mathrm{m}^{-1}\right)$ & $\mathrm{q}=1.90 \mathrm{P}^{0.0386}$ \\
& $\mathrm{R}^{2}=0.60$ \\
$\mathrm{~S} 2\left(1.5 \mathrm{dS} \mathrm{m}^{-1}\right)$ & $\mathrm{q}=1.90 \mathrm{P}^{0.0364}$ \\
& $\mathrm{R}^{2}=0.59$ \\
$\mathrm{~S} 3\left(2.5 \mathrm{dS} \mathrm{m}^{-1}\right)$ & $\mathrm{q}=1.91 \mathrm{P}^{0.0346}$ \\
S4 $\left(3.5 \mathrm{dS} \mathrm{m}^{-1}\right)$ & $\mathrm{R}^{2}=0.78$ \\
& $\mathrm{q}=1.90 \mathrm{P}^{0.0348}$ \\
$\mathrm{~S} 5\left(4.5 \mathrm{dS} \mathrm{m}^{-1}\right)$ & $\mathrm{R}^{2}=0.78$ \\
& $\mathrm{q}=1.94 \mathrm{P}^{0.0297}$ \\
& $\mathrm{R}^{2}=0.73$ \\
\hline
\end{tabular}

It was observed for all assessments that emitters were classified as self-compensating, according to the " $x$ " values, although there is a small increase in flow when pressure increases, Figures 3, 4 and 5. Pachico and Levien (2014) evaluated low-cost drip irrigation emitters submitted to low pressure and verified different behavior for self-compensating emitters, since the emitters used, although being self-compensating, presented " $x$ " exponent value near 1.0, and this fact is possibly due to the compensating behavior of emitters that worked on operating pressure between 100 and $500 \mathrm{kPa}$.
This result differs from that found in the present study, since emitters used had compensating behavior, which can be explained by the fact that emitters have been tested in the pressure range suggested by the manufacturer.

Flow rates provided by the manufacturer and the difference in flow rates obtained by equations are shown in Tables 3, 4 and 5 for new emitters, with 210 and 350 hours of operation at different salinity levels and pressures. It is accepted by ISO 9261 (ISO, 2004) that the conformation of curves may have a range of $\pm 7 \%$ compared to curves provided by the manufacturer. 
Table 3. Flow rates provided by the manufacturer, difference in flow rates obtained by the equations adjusted for new issuers at different salinity levels and pressures studied.

\begin{tabular}{|c|c|c|c|c|c|c|c|c|c|c|c|}
\hline \multirow{3}{*}{$\begin{array}{c}\text { Pressure } \\
-\mathrm{kPa}\end{array}$} & \multicolumn{11}{|c|}{ Flow $\left(\mathrm{L} \mathrm{h}^{-1}\right)$ of emitters } \\
\hline & \multirow[t]{2}{*}{$\begin{array}{c}\text { Nominal } \\
\text { flow }\end{array}$} & \multicolumn{5}{|c|}{ Adjusted flow } & \multicolumn{5}{|c|}{$\begin{array}{c}\text { Difference between nominal and adjusted } \\
\text { flow (\%) }\end{array}$} \\
\hline & & S1 & S2 & S3 & S4 & S5 & S1 & $\mathrm{S} 2$ & S3 & S4 & S5 \\
\hline 60 & 2.3 & 2.28 & 2.22 & 2.21 & 2.22 & 2.22 & 0.86 & 3.47 & 3.91 & 3.47 & 3.47 \\
\hline 100 & 2.4 & 2.36 & 2.33 & 2.31 & 2.33 & 2.33 & 1.67 & 2.91 & 3.75 & 2.91 & 2.91 \\
\hline 140 & 2.5 & 2.42 & 2.41 & 2.38 & 2.40 & 2.41 & 3.20 & 3.60 & 4.80 & 4.00 & 3.60 \\
\hline 160 & 2.6 & 2.45 & 2.45 & 2.42 & 2.43 & 2.44 & 5.76 & 5.76 & 6.92 & 6.53 & 6.15 \\
\hline
\end{tabular}

Table 4. Flow rates provided by the manufacturer, difference in flow rates obtained by the equations adjusted for emitters with 210 hours of operation at different salinity levels and pressures studied.

\begin{tabular}{|c|c|c|c|c|c|c|c|c|c|c|c|}
\hline \multirow{3}{*}{$\begin{array}{l}\text { Pressure - } \\
\quad \mathrm{kPa}\end{array}$} & \multicolumn{11}{|c|}{ Flow $\left(\mathrm{L} \mathrm{h}^{-1}\right)$ of emitters } \\
\hline & \multirow[t]{2}{*}{$\begin{array}{l}\text { Nominal } \\
\text { flow }\end{array}$} & \multicolumn{5}{|c|}{ Adjusted flow } & \multicolumn{5}{|c|}{$\begin{array}{c}\text { Difference between nominal and adjusted } \\
\text { flow (\%) }\end{array}$} \\
\hline & & S1 & S2 & S3 & S4 & S5 & S1 & $\mathrm{S} 2$ & S3 & S4 & S5 \\
\hline 60 & 2.3 & 2.20 & 2.20 & 2.20 & 2.20 & 2.20 & 4.34 & 4.34 & 4.34 & 4.34 & 4.34 \\
\hline 100 & 2.4 & 2.27 & 2.28 & 2.25 & 2.24 & 2.24 & 6.66 & 5.41 & 6.25 & 6.66 & 6.66 \\
\hline 140 & 2.5 & 2.34 & 2.34 & 2.32 & 2.32 & 2.31 & 6.40 & 6.40 & 6.40 & 7.00 & 7.00 \\
\hline 160 & 2.6 & 2.45 & 2.44 & 2.43 & 2.45 & 2.42 & 5.76 & 6.15 & 5.76 & 5.76 & 6.92 \\
\hline
\end{tabular}

Table 5. Flow rates provided by the manufacturer, difference in flow rates obtained by the equations adjusted for emitters with 350 hours of operation at different salinity levels and pressures studied.

\begin{tabular}{|c|c|c|c|c|c|c|c|c|c|c|c|}
\hline \multirow{3}{*}{$\begin{array}{c}\text { Pressure - } \\
\mathrm{kPa}\end{array}$} & \multicolumn{11}{|c|}{ Flow $\left(\mathrm{L} \mathrm{h}^{-1}\right)$ of emitters } \\
\hline & \multirow[t]{2}{*}{$\begin{array}{c}\text { Nominal } \\
\text { flow }\end{array}$} & \multicolumn{5}{|c|}{ Adjusted flow } & \multicolumn{5}{|c|}{$\begin{array}{c}\text { Difference between nominal and adjustec } \\
\text { flow (\%) }\end{array}$} \\
\hline & & S1 & S2 & S3 & $\mathrm{S} 4$ & S5 & S1 & S2 & S3 & S4 & S5 \\
\hline 60 & 2.3 & 2.22 & 2.20 & 2.20 & 2.19 & 2.19 & 3.47 & 4.34 & 4.34 & 4.78 & 4.78 \\
\hline 100 & 2.4 & 2.26 & 2.24 & 2.23 & 2.23 & 2.23 & 5.83 & 6.66 & 7.00 & 7.00 & 7.00 \\
\hline 140 & 2.5 & 2.33 & 2.32 & 2.32 & 2.35 & 2.35 & 6.80 & 7.00 & 7.00 & 6.00 & 6.00 \\
\hline 160 & 2.6 & 2.42 & 2.42 & 2.43 & 2.44 & 2.42 & 6.92 & 6.92 & 6.10 & 6.10 & 6.92 \\
\hline
\end{tabular}

It was observed that the flows obtained are close to that supplied by the manufacturer's catalogs and that percentage differences are within recommended working range (60 to $420 \mathrm{kPa}$ ), i.e., they are smaller than 7\% imposed by ISO 9261 (ISO, 2004).

Garcia (2006) found in his study on the technical evaluation of emitters for drip irrigation evaluating 25 different emitters that experimental flows determined in laboratory are close to that provided by Petro Drip and Tiran catalogs, with values higher than those provided by the manufacturer; however, the percentage differences are within the pressure range recommended by the manufacturer of 60$120 \mathrm{kPa}$ and $50-300 \mathrm{kPa}$ for Petro Drip and Tiran, respectively, although lower than the $7 \%$ required by the standard, corroborating findings of this study.

Marques and Campeche (2012); Prado et al. (2014) and Fernandes et al. (2010) evaluated uniformity in irrigation system and observed that the flow rate adjusted by exponential curve 
characteristic of the emitter followed that provided by the manufacturer, not exceeding the limit of $7 \%$ established by ISO 9261 (ISO, 2004). These results are consistent with findings in this work, even using different type of emitter.

Cunha et al. (2010), in turn, assessed emitters under field conditions and found that, when comparing nominal flow with adjusted flow, it was observed that the nominal flow was $25 \%$ higher than the adjusted flow. This may be related to the reduction of the orifice diameter of the emitter caused by the accumulation of debris due to the high salt concentration in the irrigation water.

It was observed that the differences between nominal flow and adjusted flow increased according to the salinity level of the irrigation water and to the use time of emitters; however, within acceptable limits.

\section{Conclusions}

1. The flow rate variation of self-compensating emitters has been considered to be small over time, remaining within recommendation of $\pm 7 \%$ of nominal flow. Emitters obtained exponent values between 0.02 and 0.09 , being classified as selfcompensating in accordance with manufacturer's data.

2. The manufacturing variation coefficient in all assessments was less than $5 \%$ being classified as excellent.

3. Pressure of $60 \mathrm{kPa}$ associated with electric conductivity of $0.6 \mathrm{dSm}^{-1}$ yielded flow rates near that provided by the manufacturer and the most economically viable to the farmer.

4. When the operating time increased to 210 and 350 hours, the behavior was similar to new emitters.

\section{Acknowledgment}

To Conselho Nacional de Desenvolvimento Científico e Tecnológico (CNPq) for the financial support.

\section{References}

ALMEIDA, A. M.; SAMPAIO, S. C.; SUSZEK, M. Comportamento hidráulico de gotejadores em linha lateral. Revista Varia Scientia, Cascavel, v. 6, n. 11, p. 129-140, 2006.

ALVES, W. W. A.; DANTAS NETO, J.; MATOS, J. A.; AZEVEDO, C. A. V.; LIMA, V. L. A. Variabilidade espacial de vazão e pressão em subunidade de microaspersão com emissores usados e novos. AmbiAgua, Taubaté, v. 3, n. 3, p. 67-80, 2008.

AMERICAN SOCIETY OF AGRICULTURAL ENGINEERS-ASAE. Field evaluation of microirrigation systems. St. Joseph: ASAE, 1996. 7 p.

ASSOCIAÇÃO BRASILEIRA DE NORMAS TÉCNICAS - ABNT. NBR ISO 9261: equipamentos de irrigação agrícola - emissores e tubos emissores especificações e métodos de ensaio. São Paulo: ABNT, 2006. 18 p.

CUNHA, F. N.; SILVA, N. F.; OLIVEIRA, R. C.; TEIXEIRA, M. B.; CARVALHO, J. J.; GOMES FILHO, R. R. Caracterização hidráulica de gotejadores em condição superficial e subsuperficial. Revista Brasileira de Agricultura Irrigada, Fortaleza, v. 7, n. 5, p. 317-329, 2013.

CUNHA, M. D.; CUNHA, M. L.; FREIRE, J. de O. Avaliação de desempenho do microaspersor amanco 63 $\mathrm{L} \mathrm{h}^{-1} \mathrm{em}$ condições de campo. Holos, Natal, v. 5, n. 23, p. 23-27, 2010.

DENICULI, W.; BERNARDO, S.; THIÉBAUT, J. T. L.; SEDIYAMA, G. C. Uniformidade de distribuição de água, em condições de campo num sistema de irrigação por gotejamento. Revista Ceres, Viçosa, MG, v. 27, n. 150, p. 155-162, 1980.

FERNANDES, A. L. T.; FRAGA JÚNIOR, E. F.; DAVI, F. M. M. Avaliação do desempenho de microjet's utilizados na irrigação localizada. Revista Fazu, Uberaba, v. 22 , n. 7, p. 22-26, 2010.

FERREIRA, D. F. Sisvar: Um programa para análises e ensino de estatística. Revista Symposium, Lavras, v. 6, n. 2, p. 36-41, 2008. 
FRIZZONE, J. A.; VIEIRA, A. T.; PAZ, V. P. S.; BOTREL, T. A. Caracterização hidráulica de um tubo gotejador. Revista Brasileira de Engenharia Agrícola e Ambiental, Campina Grande, v. 2, n. 3, p. 278-283, 1998.

GARCIA, C. J. B. Avaliação técnica de tubos emissores para irrigação localizada. 2006. Tese (Doutorado em Agronomia) - Universidade Estadual de São Paulo, Botucatu.

INTERNATIONAL ORGANIZATION FOR STANDARDIZATON - ISO. ISO 9621: agricultural irrigation equipment: emitters and emitting pipe: specification and test methods. $2^{\text {th }}$ ed. Geneva: BSI, 2004. $20 \mathrm{p}$.

KELLER, J.; KARMELI, D. Trickle irrigation design parameters. Transactions of the ASAE, Saint Joseph, v. 17, n. 4, p. 678-684, 1974.

LIMA, S. C.; MATOS, R. M.; GOMES, R. C. B.; SILVA, P. F.; DANTAS NETO, J. Coeficiente de variação de fabricação em gotejador autocompensante utilizando água salina. Educação Agrícola Superior, Brasília, v. 29, n. 1, p. 11-14, 2014.

MARQUES, M. A. D.; CAMPECHE, L. F. S. M. Caracterização hidráulica de emissores e testes de uniformidade de distribuição do sistema de irrigação por mini aspersão. Revista Semiárido De Visu, Petrolina, v. 2, n. 1, p. 162-175, 2012.

NAJAFI， P.; TABATABAEI， S. H.; ASGARI，K. Evaluation of filtrationand SDI application effects on treated wastewater quality index. African Journal of Agricultural Research, Benin, v. 5, n. 11, p. 1250-1255, 2010.
PACHICO, I. W. L.; LEVIEN, S. L. A. Avaliação de emissores de baixo custo de irrigação localizada submetidos à baixa pressão. Irriga, Botucatu, v. 1, p. 5561, 2014. Edição Especial.

PLETSCH, T. A.; CRUZ, R. L.; MAZZER, H. R.; OLIVEIRA, E. F. Desempenho de gotejadores com uso de esgoto doméstico tratado. Irriga, Botucatu, v. 14, n. 2 , p. 243-253, 2009.

PRADO, G.; NUNES, L. H.; TINOS, A. C. Avaliação técnica de dois tipos de emissores empregados na irrigação localizada. Revista Brasileira de Agricultura Irrigada, Fortaleza, v. 8, n. 1, p. 12-25, 2014.

RICHARDS, L. A. Diagnosis and improvement of saline and alkali soils. Washington: United States Salinity Laboratory, 1954. 160 p. (Agriculture Handbook, 60).

SILVA, L. P.; SILVA, M. M.; CORREA, M. M.; SOUZA, F. C. D.; SILVA, E. F. F. E. Desempenho de gotejadores autocompensantes com diferentes efluentes de esgoto doméstico. Revista Brasileira de Engenharia Agrícola e Ambiental, Campina Grande, v. 16, n. 1, p. 480-486, 2012.

SOLOMON, K. Manufacturing variation of trickle emitters. Transactions of the ASAE, St. Joseph, v. 22, n. 5, p. 1034-1038, 1979.

YILDIRIM, G. An assessment of hydraulic design of trickle laterals considering effect of minor losses. Journal of Irrigation and Drainage Engineering, New York, v. 56, n. 4, p. 399-421, 2007. 